\title{
DEVELOPING LEADERSHIP SKILLS THROUGH MOUNTAIN ACTIVITIES
}

\author{
Aurel MARIN ${ }^{1}$ \\ ${ }^{1}$ National University of Physical Education and Sport, Faculty of Physical Education and Sport, Bucharest, \\ Romania \\ *Corresponding author: aurel.marin@yahoo.com
}

https://doi.org/10.35189/dpeskj.2021.60.2.8

\begin{abstract}
The leadership phenomenon is probably the most studied social process known to behavioural science. Researchers believe that leadership plays a crucial role in organisations and has a direct influence on processes and their outcomes. This paper presents a critical analysis of the leadership literature. Leadership is a multilateral action by which an individual influences others to accomplish a mission, duties or objectives and guides the organisation through a method that makes it more coherent and cohesive. The mountain leader must be recognised and qualified to lead, teach, support and train clients (against payment or voluntarily) in all mountain areas of the world, regardless of season and altitude, up to the limit of permanent snow (glaciers). The leader must be honest and realistic in the relationship with themselves and find out who they are, how much they know and what they are able to do; followers (not the leader) decide whether a leader is successful. Leadership skills are important for career advancement. The current research is focused on the development of leadership skills. At the same time, ten members of a group that used to practise mountain activities on a regular basis were asked the following question: "What do you expect from a leader?". Their responses are presented in this paper, highlighting the various skills required for a leader.
\end{abstract}

Keywords: leadership, leader, mountain leader, skills.

\section{Introduction}

"In an ideal world, career success and leadership competence would go hand in hand - that is, those people who are selected for leadership positions, who are well paid, who are promoted quickly, and who are well regarded by their bosses would also motivate employees, make good decisions, and build teams that produce results over time. But there are good reasons to believe that this is not necessarily the case." (Kaiser et al., 2008, p. 102)

The attempt to define leadership is not easy at all. The word 'leadership' is taken from the common vocabulary of the English language, and researchers often define it according to their individual perspectives and the aspects that are most interesting to them.

The term 'leadership' expresses the entire influence that a person can exert on another person or a group of people so as to ensure goal achievement in an organisational framework. It is important to remember that being officially invested as the manager of a department or an organisation does not necessarily mean being the leader of that department or organisation. Leadership is a multilateral action by which an individual influences others to accomplish a mission, duties or objectives and guides the organisation through a method that makes it more coherent and cohesive.

"Leadership has also been more difficult in challenging times" (Avolio \& Gardner, 2005, p. 316). 
Fuller et al. (1996) talk about charismatic leadership, which is captivating (arouses ambivalent feelings - attracts but also scares) and has started being increasingly studied by researchers who investigate leadership and organisational behaviour.

As reported by Aronson et al. (2006), an essential feature of a strong leader is their quality of knowing how to lead the team. This quality involves coordinating group members and supporting them in their efforts, the ultimate goal being to increase team satisfaction and performance (Barczak \& Wilemon, 2001).

Leadership is both a process and a property. As a process, it involves leading the activities of group members towards the achievement of the proposed goal. As a property, leadership refers to the overall qualities attributed to those who successfully use such influence. (Jago, 1982)

In order to understand the impact of leadership on various organisations (and groups), the organisational context of leader behaviour needs to be examined (Campos et al., 2020).

In the context of the new paradigm of global economy, Bennis and Nanus (1997) recommend using the following leadership strategies:

- attention through vision - to have the picture of a mobilising programme;

- meaning through communication - communication creates meaning for people, being is the only way to get employees aligned behind the goals of an organisation; the message is clearly conveyed at all levels and represents an absolute condition that separates managers from leaders;

- trust through positioning - involves responsibility, predictability and security: it is what sells products and keeps organisations alive; involves position/visibility or knowing what is both appropriate and necessary;

- development of self through positive self-regard - recognition of strengths and compensation for weaknesses, discipline, professionalism, motivation, job satisfaction, pride in the work done, which are all reflected in the value system.

According to Bennis and Nannus (1997), the most important key factors that contribute to developing the leadership process are:

- Followers - are different and need different approaches; for example, a new employee needs more supervision than an experienced one, a low-morale employee should be approached differently than a motivated one.

- The leader - must be honest and realistic in the relationship with themselves and find out who they are, how much they know and what they are able to do; followers (not the leader) decide whether a leader is successful.

- Context/Situation - judgment must be used to decide what is the best course of action in each context/situation.

- Communication - leadership is exercised through two-way communication; nonverbal communication is used in a large percentage.

\section{Topic Addressed}

In recent years, there has been a revival of interest in addressing traits that explain how they influence leadership (Bryman, 2004). Kirkpatick and Locke (1991) argue that "effective 
leaders are different from other people in many key respects" (p. 48), adding that "it is unequivocally clear that leaders are not like other people" (p. 59).

Leaders are self-confident, persistent, very competent and willing to take risks. Leaders usually demonstrate high standards of ethical and moral conduct and avoid using power for personal gain (Bass, 1997).

Cousquer and Beames (2014) make the following statements: "That the public can trust professionals to make good decisions and resolve real-life problems stems from a confidence in their training and ability, as well as in their integrity and good intentions" (p. 10); "The increasing complexity of specialised professional practice elicits many conflicts of interest and ethical dilemmas that provide a critical test of professionalism" (p. 11); "The public's trust in a professional is also based on their confidence that they are dealing with an ethical person who can be expected to subsume their own interests to those of the client" (p. 11).

Leadership is seen by Cotterill and Fransen (2016) as "a fundamental aspect of sports performance, particularly within team sport environments" (p. 116). An expedition leader is an educated and skilled professional who is employed either privately or through an intermediary by tourists wanting to visit a remote mountainous area (Deegan, 2002).

The team leader will have a say in the team selection, being responsible for organising and conducting the expedition, and will make decisions that do not affect the well-being of the group (Cousquer, \& Allison, 2012).

Leadership refers to the ability of building an effective team; a good leader is someone that others in the group are ready to follow. Group members look for some important characteristics of leaders: determination, competence, integrity and vision. (Hogan \& Kaiser, 2005)

Some people are natural leaders, but anyone can progress to gain the skills needed for a particular practice. Learning Network (2019) has identified nine strategies that are required to develop leadership skills (Table 1).

Table 1. Nine strategies to develop leadership skills

\begin{tabular}{|c|c|c|}
\hline No. & Name & Explanations \\
\hline 1 & Discipline & $\begin{array}{l}\text { A good leader must have the notion of discipline. The development of discipline } \\
\text { in your professional (and personal) life is a requirement for being an effective } \\
\text { leader and inspire others to be disciplined. People will analyse your leadership } \\
\text { competence by the amount of discipline you display at your place of work. }\end{array}$ \\
\hline 2 & More projects & $\begin{array}{l}\text { A method used to develop your leadership skills is to take more responsibility. } \\
\text { You must get out of your comfort zone in order to learn something new, and this } \\
\text { will be noticed by others. }\end{array}$ \\
\hline 3 & Learn to follow & $\begin{array}{l}\text { A true leader has no problem transferring control to another individual when } \\
\text { appropriate. You should never feel endangered when someone disagrees with } \\
\text { you, doubts your thinking or has personal opinions. If you get used to value and } \\
\text { respect your teammates, they will be more receptive and will join you. }\end{array}$ \\
\hline 4 & Situational analysis & $\begin{array}{l}\text { A good leader is an individual who has an overview and can sense difficulties } \\
\text { before they arise, which is why it is an important skill when having to manage } \\
\text { complicated projects with deadlines. The ability to intuit and give suggestions to } \\
\text { avoid possible problems should be appreciated in a leader. This ability helps you } \\
\text { identify opportunities that some people overlook. }\end{array}$ \\
\hline 5 & Inspire others & $\begin{array}{l}\text { Being a leader means being part of a team. As a leader, you need to motivate and } \\
\text { inspire as best as possible those with whom you work or collaborate. When a team } \\
\text { member needs guidance and encouragement, you have to support them. }\end{array}$ \\
\hline
\end{tabular}




\begin{tabular}{ccl}
\hline 6 & Keep learning & $\begin{array}{l}\text { The best way to become a good leader is to constantly improve yourself and learn } \\
\text { new things. This keeps your mind sharp and your skills fresh. Learning prepares } \\
\text { you for new challenges. }\end{array}$ \\
7 & $\begin{array}{l}\text { The sooner you realise that no one is the best at everything, the sooner you can } \\
\text { learn to be a good leader. Delegating tasks to others not only saves you from doing } \\
\text { things that you already do well but empowers other people in your team. }\end{array}$ \\
8 & Resolve conflicts & $\begin{array}{l}\text { Interpersonal conflicts should not be ignored. A good leader should treat conflicts } \\
\text { by talking to those involved. You should be open to reassign the team members } \\
\text { if the conflict cannot be resolved. } \\
\text { A leader does not always have to be in the spotlight. An essential quality of a } \\
\text { good leader is to listen to others' ideas, suggestions and be open to their feedback. }\end{array}$ \\
\hline Source: Learning Network (2019) & $\begin{array}{l}\text { Be a discerning } \\
\text { listener }\end{array}$
\end{tabular}

Leadership skills are important for career advancement. As John Quincy Adams said: "If your actions inspire others to dream more, learn more, do more and become more, you are a leader".

\section{Group management and mountain leader tasks:}

Specific tasks:

a) to establish goals appropriate to both the experience, skills and degree of motivation of the group and the dominant situations;

b) to design or monitor and take into account planning (for example, personal and medical information, finance, insurance and transport, parental consent);

c) to work out the details (for example, route planning, checking access, obtaining weather forecasts and transmitting information to the group);

d) to ensure that the group is properly trained for the activity carried out;

e) to pay due attention to the legislation in force regarding the activities carried out.

Practical tasks in the mountains:

a) to exercise the leadership, administration and supervision of the group by establishing and reviewing the objectives, conducting risk assessments, delegating where appropriate, controlling the group, making effective decisions, maintaining rules and good communication;

b) to focus on the changing needs of the organised group by paying special attention to the health and physical condition of its members, by maintaining safety and enthusiasm;

c) to provide any group member with all the acquired safe knowledge while displaying attention, involvement, entertainment and satisfaction, spreading appropriate technical skills and protecting the environment;

d) to assess the experience of group members and to argue why they should participate in a new expedition;

e) to monitor groups by division (for example, according to age, gender or religion) as well as unaccompanied persons during their walks or expeditions.

Leadership and personal skills:

a) showing a docile leadership style and persuasive thoughts about the group and its goals;

b) applying good practices regarding personal skills: foot placement, energy storage, pace, stability and coordination;

c) making suitable route options, analysing and estimating the type of terrain, checking the routes if necessary; 
d) establishing and managing the risk;

e) being competent to guide a group on steep terrain using appropriate techniques and demonstrating reliable skills to be responsible and able to supervise the group.

\section{Travelling}

It is essential for a mountain leader to be able to move skilfully. The mountain leader must choose the right travel technique for specific situations and be able to teach others these skills.

Mountain leaders should be familiar with topographic maps, scales and conventional signs, be able to relate the map to the terrain and vice versa, measure the distance on the map and the terrain, move around the country only with the map, use compasses and other travel aids, find ways to recognise routes and positions, find ways to relocate, find ways to travel throughout the country in low visibility and/or in the dark, plan the route and route recording methods, allows access to the environment.

Mountain leaders must:

a) guide and enliven the groups in the mountains, constantly widen their sphere of action and competences as well as observe the environment;

b) prove that they know the current relevant legislation regarding travel and access rights and the importance of access agreements and codes;

c) prove that they are trained for managing terrains in mountain areas and their multiple use (for example, forestry, hill agriculture, water collection, etc.);

d) prove that they have knowledge of the current relevant conservation legislation and assess the conservation difficulties regarding fauna, flora and erosion. They need to perceive the nature of the specially indicated areas and any limitations of their use and be aware of the longterm effects of human pressures on the environment;

e) know how to obtain information on access to a wild country (for example, to document themselves through maps, appropriate guides, relevant mountaineering bodies and websites);

f) be accustomed to relevant codes in rural areas and be aware of the individual's obligation to reduce environmental impact.

\section{Obstacles and emergency formalities}

There are different categories of danger that might occur in the mountains.

- Steep terrain obstacles - mountain leaders should know the techniques to ensure safe movement on steep terrain. This should be done through well-organised planning, route selection and group management. Situations may arise in which the rope/cord is useful to protect group members. The leader should identify such inconveniences and potential dangers that could lead to the use of simple rope techniques to provide confidence or safety. Leaders should be familiar with: matching all sizes and lengths of ropes/cords, making appropriate knots, providing proper safety methods, choosing secure anchors.

- Environmental threats - mountain-specific threats include falling rocks, avalanches, floods and lightning. A mountain leader should have strong judgment to remove these dangers, to know how to deal with them. 
- Water threats (including swamps, streams and rivers) - involve skills, procedures and safety training for the leader and group members, methods to avoid dangers, choosing the best crossing places and techniques.

Regarding leadership skills, an innate basis that can be refined is needed as well as a stable concern for the development of skills that a true leader should possess. There are individuals who, although they have the ability to be leaders, do not exploit it. On the other hand, there are individuals who are eager to become leaders and manage to balance their lack of innate leadership qualities.

To lead a group, a department or a company involves assuming a very complex attitude. One cannot say that a person is born fully prepared to manage all possible circumstances and social relationships encountered in a leadership position. There are some defining features that predispose certain individuals to become leaders (Hipo, 2021):

\section{Extraverted nature}

Extraverted individuals seem to have more opportunities to hold a leadership position due to a greater ease through which they manage to express their opinions and make others accept them. Extraverts communicate more effectively and are more capable to coordinate a group/ team than introverted individuals. Extraverted nature is not enough but is indispensable to gain a leadership position.

2. Audacity

Individuals who risk using ideas have an increased ability to hold a leadership position. Only those who sit in the front row and take the initiative have the opportunity to be accepted by others as leaders. Audacity is a character trait that can be perfected throughout one's career and life and is dependent on self-confidence.

3. Risk-taking

Audacity involves being open to risk. Leadership is focused on innovation, and innovation cannot exist without risk. Individuals who are willing to take risks have the opportunity to get a leadership role, unlike those who make comfortable decisions. It is essential for leaders to have the ability to communicate to their teams/groups the possible effects of their decisions so that team/group members accept in their turn the failure/success.

\section{Intelligence}

The leader must be competent, investigate all facets of the circumstances encountered and make the correct decisions following these investigations. The leader must be smart and have, besides an above-average intelligence quotient (IQ), a high emotional intelligence quotient (EQ). Employees with a high EQ take advantage of their cognitive and emotional abilities and reach the leading position. The leader is attentive to the development of both crystallised intelligence and emotional intelligence to understand all situations as effectively and deeply as possible. Emotional intelligence becomes more important as an employee gets promoted in the company. Team or group leaders must be competent enough to adjust their emotions to those of team members, thus establishing an appropriate climate within the team. To make the best decisions, leaders must have a high level of emotional intelligence.

\section{Empathy}

The words of Bass (a psychologist and university professor with an important contribution in the field of leadership) (1997) best reflect the importance of empathy for a leader: "The leader must be able to know what followers want, when they want it, and what prevents them 
from getting what they want". However, these innate qualities are not enough for someone to be a successful leader. Today, there are many development programmes (courses, free webinars, training sessions, conferences, etc.) through which individuals can learn how to improve their skills or how to balance the missing ones.

Everyone can be a leader, but good leadership is often learned by making mistakes, covering a route through an organisation or observing managers who are good and others who are less good. There are five important leadership skills that can be developed during an expedition in the mountains (Alvernaz, 2019):

1. Sharing the success

In a climbing expedition, you experience a lot of things, but you are never alone. You are dependent on your partner or team/group to reach your destination or get to the summit. Although you could probably get to the top of the mountain by yourself, you will have much greater satisfaction (in terms of both achievement and journey/adventure) if you get there with a team or group.

A shared journey is more important than the final destination. If the achievement is not shared and celebrated together with the team or group, what is the use of it? In a team or group, there is no "I", which is why success is shared with the others. You just need to think about how much you have accomplished and you will accomplish due to your team (and you will understand that this surpasses by far anything you would have been able to do by yourself).

2. Using perseverance, patience and gratitude

When you are in the woods, on the mountain, the big concerns of your everyday life seem less important and you begin to appreciate many little things in life (particularly when your cell phone has no signal). You become aware that perseverance and patience are crucial for you to keep moving. Climbing a mountain is not easy at all. You can encounter both physical difficulties and mental challenges that may lead you to extreme situations. Although you feel exhausted, you need to find the energy to continue even if the attempts may take several hours, days, weeks or months. It is like figuring out that you can do whatever you want, such as reaching a goal or achieving a dream. You know that the reward will certainly be worthwhile.

You should stop for a moment and make time to appreciate your own work but also the work done by your teammates. You should thank more often for any service provided to you. You should always show your gratitude to the team or group to which you belong. In the case of remote work, perseverance and patience are needed to gain profitable stability.

We and only we are responsible for our choices, and no one else. Smart leaders know that they should not expect results overnight. They need to train their perseverance and patience skills in order to motivate their team or group to do the same.

If there are too many difficulties in your way, just step back and make another attempt the next day: you will thus realise how many things you have done to get to that point and you will consider your challenges from a different perspective. "Where there's a will, there's a way", as an old English proverb says.

\section{Nurturing emotional intelligence}

During an expedition in the mountains, you should know that there are various obstacles to success (cold, fatigue, shortness of breath, fear and failure). You need to be in good shape, with your body and mind equally strong to support you when facing difficulties. Climbing is $20 \%$ 
physical and $80 \%$ mental. You can train your psychological health by struggling to gain experience and build appropriate self-awareness.

Even though you have all the necessary skills to succeed, you may suffer from the impostor syndrome or an "I am not good enough" attitude while doing your work, and then your chances of reaching your goal will considerably decline. You need to find out if you can control your anxiety, temper or fear of failure. You also need to see how you react to the feedback provided by other people.

The mountain is a wonderful environment to train your emotional intelligence. You need to listen to your inner voices while moving. What do you say to yourself? What words do you use? Are these words positive or negative?

4. Being open to change

In the mountains, the weather is unstable and changes from one moment to the next. Even if you plan your expedition in advance, things can suddenly get out of control: a group or team member gets injured, a strong wind takes your tent through the valley, a snowstorm comes earlier than expected, etc. You need to adapt to any situation, be able to change your plans and make proper decisions based on the facts and instruments available to you at that moment.

You need to be flexible enough to accept constant change. There will always be changes in this world and what you are doing today might not be identical to what you will be doing in six months or a year. As a professional leader, you may be forced to climb mountains in extreme weather, which is why you need to be skilful in those times of fluctuations and uncertainty. You need to respond to events quickly and show positive thinking. If you reach this phase, you will find out that this is a trait of a successful leader and group or team.

\section{Building a lot of trust}

Ten members (six men and four women aged between 24 and 68 years) of a group that used to practise mountain activities on a regular basis were asked the following question: "What do you expect from a leader?". Their responses are presented below.

Thus, in their opinion, the leader should:

- be reliable and possess successful skills;

- understand what happens if circumstances change;

- have motivation and potential for success;

- have time to raise the spirits of the team/group;

- perform activities that show the team/group what they have to do together;

- work with the team/group, encouraging everyone to participate for achieving the proposed goals;

- know how to impose rules and have the same expectations from each member of the team/group, without making exceptions;

- be an optimistic person and see beyond the problems and obstacles that arise;

- be interested in what the team/group needs so that they manage to achieve the goals together;

- be able to perform activities with which the team/group members are accustomed and teach them new skills so that they can face new challenges.

As can be seen, each member focused on a different leadership skill. 


\section{Conclusion}

An essential skill for any leader is the ability to build trust within a team or group. However, this is not enough, you also need to build trust in yourself. You need to get used to the strengths and weaknesses of others. Time and experience are required to trust your feet and your ability to climb. Communication and transparency are crucial to building "a mountain of trust".

If someone gets injured or feels sick, the team or group should be informed about this. Not everyone in the team or group is able to master the different rescue methods (members must be aware of the complexity of situations that may arise in the mountains/during an expedition). Trust is an important investment for a productive and safe workplace; therefore, all people should progress and develop it as a leadership skill. If a leader trusts their team or group to get the desired outcome, then there is no need for the micro-management of every project/step.

Most of the conditions and experiences encountered in both the mountains and daily activities are also applicable to professional life. Remember that many leadership skills can be strengthened in the mountains. Edmund Hillary, the first man to conquer Mount Everest, once said: "It is not the mountain we conquer but ourselves". Every mountain can teach us something about ourselves if we are willing to see it from the top. (Alvernaz, 2019)

\section{References}

Alvernaz, A. (2019). 5 leadership skills you can develop in the mountains. https://blog.trello.com/leadership-skills-you-can-develop

Aronson, Z. H., Reilly, R. R., \& Lynn, G. S. (2006). The impact of leader personality on new product development teamwork and performance: The moderating role of uncertainty. Journal of Engineering and Technology Management, 23(3), 221-247. https://doi.org/10.1016/j.jengtecman.2006.06.003

Avolio, B. J., \& Gardner, W. L. (2005). Authentic leadership development: Getting to the root of positive forms of leadership. The Leadership Quarterly, 16(3), 315-338. https://doi.org/10.1016/j.leaqua.2005.03.001

Barczak, G., \& Wilemon, D. (2001). Factors influencing product development team satisfaction. European Journal of Innovation Management, 4(1), 32-36. https://doi.org/10.1108/14601060110365556

Bass, B. M. (1990). Bass \& Stogdill's handbook of leadership: Theory, research, and managerial applications (3rd ed.). The Free Press.

Bass, B. M. (1997). Does the transactional-transformational leadership paradigm transcend organizational and national boundaries? American Psychologist, 52(2), 130-139. https://doi.apa.org/doi/10.1037/0003-066X.52.2.130

Bennis, W., \& Nanus, B. (1997). Leaders: Strategies for taking charge. Harper Business.

Bryman, A. (2004). Qualitative research on leadership: A critical but appreciative review. The Leadership Quarterly, 15(6), 729-769. https://doi.org/10.1016/j.leaqua.2004.09.007

Campos, J. A., Aubert, A., Guo, M., \& Joanpere, M. (2020). Improved leadership skills and aptitudes in an Excellence EMBA Program: Creating synergies with dialogic leadership to achieve social impact. Frontiers in Psychology, 11: 17.

https://doi.org/10.3389/fpsyg.2020.00017

Cotterill, S. T., \& Fransen, K.(2016). Athlete leadership in sport teams: Current understanding and future directions. International Review of Sport and Exercise Psychology, 9(1), 116133. http://dx.doi.org/10.1080/1750984X.2015.1124443 
Cousquer, G., \& Allison, P. (2012). Ethical responsibilities towards expedition pack animals: The mountain guide's and expedition leader's ethical responsibilities towards pack animals on expedition. Annals of Tourism Research, 39(4), 1839-1858. https://doi.org/10.1016/j.annals.2012.05.001

Cousquer, G. O., \& Beames, S. (2014). Professionalism in mountain tourism and the claims to professional status of the International Mountain Leader. Journal of Sport and Tourism, 18(3), 185-215. https://doi.org/10.1080/14775085.2014.904246

Deegan, P. (2002). The mountain traveller's handbook: Your companion from city to summit. Gardners Books.

Fuller, J. B., Patterson, C. E. P., Hester, K. I. M., \& Stringer, D. Y. (1996). A quantitative review of research on charismatic leadership. Psychological Reports, 78(1), 271-287. http://dx.doi.org/10.2466/pr0.1996.78.1.271

Hipo. (2021). Abilităţile de lider - înnăscute sau construite? [Leadership skills - innate or built?]. https://www.hipo.ro/locuri-de-munca/vizualizareArticol/848/Abilitatile-de-lider$\% \mathrm{EF} \% \mathrm{BF} \% \mathrm{BD}$-innascute-sau-construite\%3F

Hogan, R., \& Kaiser, R. B. (2005). What we know about leadership. Review of General Psychology, 9(2), 169-180. https://doi.org/10.1037/1089-2680.9.2.169

Jago, A. G. (1982). Leadership: Perspectives in theory and research. Management Science, 28(3), 315-336. https://doi.org/10.1287/mnsc.28.3.315

Kaiser, R. B., Hogan, R., \& Craig, S. B. (2008). Leadership and the fate of organizations. American Psychologist, 63(2), 96-110. https://doi.org/10.1037/0003-066x.63.2.96

Kirkpatick, S. A., \& Locke, E. A. (1991). Leadership: Do traits matter? The Executive, 5(2), 48-60. https://doi.org/10.5465/ame.1991.4274679

Learning Network. (2019). Leadership: 9 strategii de dezvoltare a abilităților [Leadership: 9 skill development strategies]. https://www.learningnetwork.ro/articol/leadership-9strategii-de-dezvoltare-abilitatilor/5663 